\title{
HUBUNGAN PENCEMARAN SUMBER AIR DAN PERILAKU IBU DENGAN KEJADIAN DIARE PADA ANAK BALITA DI DESA SIRKANDI KECAMATAN PURWAREJA KLAMPOK KABUPATEN BANJARNEGARA TAHUN 2016
}

\author{
Winenti*), Teguh Widiyanto ${ }^{* *}$, Arif Widyanto ${ }^{* * *}$ \\ Jurusan Kesehatan Lingkungan, Politeknik Kesehatan Kemenkes Semarang, \\ Jl.Raya Baturaden KM 12 Purwokerto, Indonesia
}

\begin{abstract}
Abstrak
Diare adalah penyakit yang menjadi penyebab utama kedua kematian anak dibawah usia lima tahun. Pencemaran sumber air sebagai faktor lingkungan yang berinteraksi dengan faktor perilaku merupakan faktor yang paling berpengaruh dalam kejadian diare. Penelitian ini bertujuan untuk mengetahui hubungan pencemaran sumber air dan perilaku ibu yang terdiri dari perilaku mencuci tangan, perilaku merebus air, perilaku menyimpan air minum dan perilaku membuang tinja balita dengan kejadian diare pada balita. Jenis penelitian ini merupakan penelitian observasional dengan analisis deskriptif dan menggunakan pendekatan cross sectional. Populasi dalam penelitian ini adalah ibu balitadi Desa Sirkandi yang berjumlah 689 dengan jumlah sampel sebanyak 69 sampel. Data dianalisis dengan menggunakan uji chi square. Pengambilan sampel dengan cara acak sederhana (simple random sampling). Pengumpulan data dilakukan dengan cara wawancara, observasi dan inspeksi sanitasi. Hasil penelitian menunjukkan bahwa dari 69 responden terdapat 45 responden $(65,2 \%)$ yang mempunyai balita menderita diare. Dengan $\alpha=0,05$ ada hubungan yang signifikan anatara pencemaran sumber air ( $p$ value $=0,033, O R=3,45$ ), perilaku mencuci tangan ( $p$ value $=0,000, O R=51,25)$, perilaku merebus air ( $p$ value $=0,000, O R=8,75)$, perilaku menyimpan air minum ( $p$ value $=0,000, O R=19,25)$ dan perilaku membuang tinja balita ( $p$ value $=$ $0,000, O R=88,00)$ dengan kejadian diare pada balita. Kesimpulan penelitian ini adalah ada hubungan yang signifikan antara pencemaran sumber air, perilaku mencuci tangan, perilaku merebus air, perilaku menyimpan air minum dan perilaku membuang tinja balita dengan kejadian diare pada balita. Saran yang diberikan yaitu dengan melakukan pengawasan atau inspeksi sanitasi sumber air oleh petugas dan memberikan sosialisasi dan penyuluhan kepada masyarakat tentang pencegahan diare melalui penerapan perilaku hidup bersih dan sehat.
\end{abstract}

Kata kunci: diare, pencemaran, perilaku

\begin{abstract}
[The Relationship Between Pollution Of Water Sources And Mother Behavior With The Incidence Of Diarrhea In Children Under Five Years Old In Sirkandi Rural Purwareja Klampok District Banjarnegara Regency 2016] Diarrhea is the main causes of death desease in children under five years old. Water sources pollution as environmental factor that interact with behavioral factor is the most influential factor inthe incidence of diarrhea. The research aims to detrmine the relathioship of pollution water source and mother behavior that consists of hand washing, boiling water, store of drinking water and dispose of feces with the incidence of diarrhea in children under five years old. The research is an observational research with descriotive analysis and cross sectional approach.Population in this research were mother of children under five years old in Sirkandi rural which amount is 689 with total sampel of 45 sampels.Data wer analyzed using chi-square. Sampling with simple random sampling. Data was collected by interview, observation and inspection of water sources inspection. The results showed that out of 69 respndents there were 45 respndents $(65,2 \%)$ who have children under five year old suffer from diarrhea, with $\alpha=0,05$ there is a significant relationship between water source pollution ( $\mathrm{p}$ value $=$ $0,033, O R=3,45$ ), behavioral of mother in hand washing (p value $=0,000, O R=51,25)$, boiling water ( $\mathrm{p}$ value $=$ $0,001, O R=8,75$ ), store of drinking ( $\mathrm{p}$ value $=0,000, O R=19,25$ ) and dispose of feces ( $\mathrm{p}$ value $=0,000 \mathrm{OR}=$ $88,0)$ with the incidence of diarrhea in children under five years old. Conclisions of the research is there are significant relationship between water source pollution and mother behavioral with the incidence of diarrhea in
\end{abstract}


children under five years old.Advice given is to conduct surveillance and sanitary inspection of water sources by officials and disseminating information and educate the public about prevention of diarrhea through the implementation of higiene and sanitation of water sources and clean and healthy behaviors.

Keywords: diarrhea, water sources pollution, behavioral

\section{Pendahuluan}

Penyakit diare merupakan salah satu penyakit berbasis lingkungan. Penyakit berbasis lingkungan masih merupakan masalah utama kesehatan terbesar masyarakat Indonesia. Hal ini tercermin dari tingginya angka kejadian diare pada sarana pelayanan kesehatan (Dinkes Prop Jateng, 2005).

Tingginya kejadian diare disebabkan oleh masih buruknya kondisi sarana sanitasi dasar terutama air bersih dan jamban, meningkatnya pencemaran, kurang higienisnya cara pengolahan makanan, rendahnya perilaku hidup bersih dan sehat (Dinkes Prop Jateng, 2005).

Desa Sirkandi merupakan salah satu wilayah kerja Puskesmas Purwareja Klampok 2, Kecamatan Purwareja Klampok, Kabupaten Banjarnegara, Propinsi Jawa Tengah, yang mempunyai angka kejadian diare tertinggi. Berdasarkan data dari Puskesmas Purwareja Klampok 2 penderita diare di Desa Sirkandi pada tahun 2014 sebanyak 425 penderita dengan jumlah diare pada balita sebanyak 187 penderita. Pada tahun 2015 sebanyak 587 penderita dengan jumlah diare pada balita sebanyak 308 penderita.

Selain mempunyai angka kejadian diare tinggi, Desa Sirkandi juga mempunyai permasalahan berupa cakupan sanitasi dasar yang rendah. Hal ini dapat dilihat dari cakupan jamban keluarga yang baru mencapai $63,8 \%$. Masalah sanitasi lainnya yang ada di Desa Sirkandi adalah sumber air bersih yang tidak memenuhi syarat sehingga tingkat risiko pencemarannya tinggi.

Permasalahan kesehatan lainnya yang ada di Desa Sirkandi adalah rendahnya perilaku hidup bersih dan sehat, seperti perilaku mencuci tangan pakai sabun yang baru mencapai $42,5 \%$, perilaku merebus air yang tidak sampai mendidih, perilaku menyimpan air dalam wadah yang tidak tertutup dan perilaku membuang tinja bayi atau balita yang tidak dimasukkan ke dalam jamban tetapi dibuang ke kebun atau saluran air (Puskesmas Purwareja Klampok 2, 2014) .

\footnotetext{
*)E-mail:winentihs@ gmail.com

**) E-mail : widiyantoteguh@yahoo.co.id

***)E-mail: arifwidyanto74@yahoo.com
}

Banyak faktor yang secara langsung maupun tidak langsung dapat menjadi faktor pendorong terjadinya diare, terdiri dari faktor agent, penjamu, lingkungan dan perilaku. Faktor lingkungan yang paling dominan sebagai faktor risiko diare yaitu sarana air bersih dan pembuangan tinja. Kedua faktor ini akan berinteraksi bersama dengan perilaku manusia. Apabila faktor lingkungan tidak sehat karena tercemar kuman diare serta berakumulasi dengan perilaku manusia yang tidak sehat maka penularan diare akan lebih mudah terjadi (Depkes, 2005).

\section{Bahan dan Metode}

Penelitian ini merupakan penelitian observasional dengan analisis deskriptif dan menggunakan pendekatan cross sectional. Populasi dalam penelitian ini adalah balita di Desa Sirkandi pada bulan Januari 2016 yang berjumlah 689 dengan jumlah sampel sebanyak 69 sampel. Data dianalisis dengan menggunakan uji chi square. Pengambilan sampel dengan cara acak sederhana (simple random sampling). Pengumpulan data dilakukan dengan cara wawancara, observasi dan inspeksi sanitasi, dengan menggunakan panduan wawancara penderita diare di klinik sanitasi dan form inspeksi sanitasi srana air bersih.

\section{Hasil dan Pembahasan}

Analisis Univariat

1. Kejadian Diare pada Balita di Desa Sirkandi, Kecamatan Purwareja Klampok, Kabupaten Banjarnegara

Kejadian diare yang dimaksud pada penelitian ini adalah diare yang disebabkan oleh infeksi dengan gejala buang air besar lebih dari 3 kali dalam sehari, dengan konsistensi lembek sampai encer, disertai panas, muntah, tinja berlendir atau berdarah. Angka kejadian diare pada balita di Desa Sirkandi dapat dilihat pada tabel berikut: 
Tabel 1

Distribusi Frekuensi Kejadian Diare di Desa Sirkandi, Kecamatan Purwareja Klampok, Kabupaten Banjarnegara Tahun 2016

\begin{tabular}{clcc}
\hline No. & $\begin{array}{c}\text { Kejadian } \\
\text { Diare }\end{array}$ & Jumlah & $\begin{array}{c}\text { Persentase } \\
(\%)\end{array}$ \\
\hline 1. & Diare & 45 & 65,2 \\
2. & Tidak Diare & 24 & 34,8 \\
\hline & Jumlah & 69 & 100,0 \\
\hline & Berdasarkan tabel 47 diketahui dari 69
\end{tabular}
responden terdapat $45(65,2 \%)$ mempunyai balita menderita diare, dan 24 responden $(34,2 \%)$ mempunyai balita tidak menderita diare.

Diare merupakan salah satu penyebab angka kematian dan kesakitan tertinggi pada anak, terutama pada anak umur kurang dari lima tahun (balita). Anak mengalami diare sebanyak 1,3 episode per tahun. Bayi dan balita rentan sekali terkena diare, karena perkembangan sistem pencernaan dan kekebalan tubuhnya yang belum optimal, sehingga mereka mudah terserang diare akibat virus atau bakteri.

Angka kejadian diare pada balita yang tinggi di Desa Sirkandi, Kecamatan Purwareja Klampok, Kabupaten Banjarnegara, disebabkan oleh banyak faktor, terutama faktor lingkungan yang terdiri dari air bersih dan jamban keluarga, serta faktor perilaku ibu yang kurang higienis seperti perilaku ibu dalam mencuci tangan, merebus air, menyimpan air minum dan membuang tinja balita

\section{Tingkat risiko pencemaran sumber air bersih}

Tingkat risiko pencemaran sumber air bersih yang digunakan penduuduk Desa Sirkandi, Kecamatan Purwareja Klampok, Kabupaten Banjarnegara Tahun 2016 diperoleh hasil sebagai berikut:

Tabel 2

Distribusi Frekuensi Tingkat Risiko Pencemaran Sumber Air Bersih yang Digunakan di Desa Sirkandi, Kecamatan Purwareja Klampok, Kabupaten Banjarnegara Tahun 2016

\begin{tabular}{|c|c|c|c|}
\hline No. & $\begin{array}{c}\text { Tingkat Risiko } \\
\text { Pencemaran SAB }\end{array}$ & Jumlah & $\begin{array}{c}\text { Persentase } \\
(\%)\end{array}$ \\
\hline 1. & $\begin{array}{ll}\text { Rendah dan } \\
\text { Sedang }\end{array}$ & 27 & 39,1 \\
\hline 2. & Tinggi & 42 & 60,9 \\
\hline & Jumlah & 69 & 100,0 \\
\hline
\end{tabular}

Menurut tabel 4.8 sumber air bersih yang digunakan responden di Desa Sirkandi, Kecamatan Purwareja Klampok, Kabupaten Banjarnegara mempunyai tingkat risiko pencemaran rendah dan sedang 27 sarana $(39,1 \%)$ dan tingkat risiko pencemaran tinggi 41 $(60,9 \%)$ sarana.

Berdasarkan hasil penelitian diketahui bahwa tingkat risiko pencemaran sumber air yang digunakan responden adalah 42 dari 69 $(60,9 \%)$ mempunyai risiko pencemaran tinggi. Sumber air bersih yang digunakan sebagian besar responden adalah sumur gali. Berdasarkan hasil inspeksi sanitasi sarana air bersih yang dilakukan, variabel yang yang tidak terpenuhi adalah: jarak dengan tempat pembuangan tinja kurang dari 10 meter, keretakan pada lantai sumur, bibir sumur tidak diplester sedalam 3 meter, lantai sumur tidak kedap air dalam radius 1 meter, serta tidak berfungsinya saluran pembuangan air limbah.

Sarana air bersih lain yang digunakan oleh responden di Desa Sirkandi, Kecamatan Purwareja Klampok, Kabupaten Banjarnegara adalah mata air. Hasil inspeksi sanitasi sarana air bersih menunjukkan bahwa variabel penilaian yang tidak terpenuhi adalah sumber mata air tidak terlindungi oleh batu bata atau beton atau kotak mata air terbuka, sehingga masih memungkinkan masukknya pencemar ke dalam mata air. Variabel penilaian lain yang tidak terpenuhi yaitu masih memungkinkannya hewan masuk ke dalam mata air tersebut sehingga memungkinkan pencemaran sumber air oleh hewan tersebut.

3. Perilaku Ibu dalam Mencuci Tangan

Berdasarkan tabel 4.9 dapat diketahui perilaku ibu dalam mencuci tangan di Desa Sirkandi, Kecamatan Purwareja Klampok, Kabupaten Banjarnegara tahun 2016 adalah 45 $(65,2 \%)$ berperilaku tidak higienis atau tidak melakukan cuci tangan pakai sabun sesudah buang air besar, 24 (34,8\%) berperilaku higienis atau melakukan cuci tangan pakai sabun sesudah buang air besar.

Tabel 3

Distribusi Frekuensi Perilaku Ibu dalam Mencuci Tangan di Desa Sirkandi, Kecamatan Purwareja Klampok, Kabupaten Banjarnegara Tahun 2016

\begin{tabular}{clcc}
\hline No. & $\begin{array}{c}\text { Perilaku } \\
\text { Mencuci Tangan }\end{array}$ & Jumlah & $\begin{array}{c}\text { Persentase } \\
(\%)\end{array}$ \\
\hline 1. & Tidak higienis & 35 & 65,2 \\
2. & Higienis & 24 & 34,8 \\
\hline
\end{tabular}




$$
\text { Jumlah }
$$

69

100,0

4. Perilaku Ibu dalam Merebus Air

Perilaku responden dalam melakukan pengolahan air minum sebelum dikonsumsi adalah dengan cara merebus air, akan tetapi dalam merebus air ada yang merebus air sampai mendidih hingga minimal lima menit, ada pula yang merebus air tetapi tidak sampai mendidih selama minimal lima menit.

Tabel 4

Distribusi Frekuensi Perilaku Ibu dalam Merebus Air di Desa Sirkandi, Kecamatan PurwarejKlampok, Kabupaten Banjarnegara Tahun 2016

\begin{tabular}{clcc}
\hline No. & $\begin{array}{c}\text { Perilaku Merebus } \\
\text { Air }\end{array}$ & Jumlah & $\begin{array}{c}\text { Persentase } \\
(\%)\end{array}$ \\
\hline 1. & Tidak higienis & 25 & 36,2 \\
2. & Higienis & 44 & 63,8 \\
\hline & Jumlah & 69 & 100,0
\end{tabular}

Dari tabel 4.10 diketahui bahwa perilaku ibu balita dalam merebus air adalah $25(36,2 \%)$ masuk kategori tidak higienis, $44(63,8 \%)$ berperilaku higienis.

5. Perilaku Ibu dalam Menyimpan Air Minum

Perilaku responden dalam menyimpan air minum setelah dimasak untuk dikonsumsi yaitu dengan menyimpan dalam wadah yang tertutup seperti ceret/eskan dan panci, tetapi ada pula yang menyimpannya dalam wadah yang tidak tertutup seperti botol bekas sirup, panci yang tidak ada tutupnya ataupun wadah lain yang tidak tertutup.

Tabel 5

Distribusi Perilaku Ibu dalam Menyimpan Air

Minum di Desa Sirkandi, Kecamatan Purwareja

Klampok, Kabupaten Banjarnegara Tahun 2016

\begin{tabular}{llcc}
\hline No. & \multicolumn{1}{c}{$\begin{array}{c}\text { Perilaku } \\
\text { Menyimpan Air } \\
\text { Minum }\end{array}$} & Jumlah & $\begin{array}{c}\text { Persentase } \\
(\%)\end{array}$ \\
\hline 1. & Tidak higienis & 36 & 52,2 \\
2. & Higienis & 33 & 47,8 \\
\hline & Jumlah & 69 & 100,0 \\
\hline
\end{tabular}

Berdasarkan tabel 4.11 diketahui bahwa perilaku ibu balita dalam menyimpan air minum adalah 36 responden $(52,2 \%)$ masuk kategori tidak higienis, 33 responden $(47,8 \%)$ berperilaku higienis.

6. Perilaku Ibu dalam Membuang Tinja Balita
Perilaku responden dalam membuang tinja balita bermacam macam yaitu dibuang ke kebun, selokan, saluran pembuangan air limbah dan ada pula yang dibuang ke tempat pembuangan tinja (septic tank, cubluk).

Tabel 6

Distribusi Perilaku Ibu Balita dalam Membuang Tinja Balita di Desa Sirkandi, Kecamatan Purwareja Klampok, Kabupaten Banjarnegara Tahun 2016

\begin{tabular}{clcc}
\hline No. & \multicolumn{1}{c}{$\begin{array}{c}\text { Perilaku } \\
\text { membuang tinja } \\
\text { balita }\end{array}$} & Jumlah & $\begin{array}{c}\text { Persentase } \\
(\%)\end{array}$ \\
\hline 1. & $\begin{array}{l}\text { Tidak memenuhi } \\
\text { syarat }\end{array}$ & 42 & 60,9 \\
2. & Memenuhi syarat & 27 & 39,1 \\
\hline & Jumlah & 69 & 100,0 \\
\hline
\end{tabular}

Berdasarkan tabel 4.12 diketahui bahwa perilaku ibu balita dalam membuang tinja bayi/balita adalah 42 (60,9\%) masuk kategori tidak memenuhi syarat, yaitu dibuang ke kebun, tempat sampah, selokan atau saluran pembuangan air limbah sedangkan $27(39,1 \%)$ dibuang pada tempat yang memenuhi syarat yaitu ke tempat penampungan tinja.

\section{Analisis Bivariat}

\begin{tabular}{|c|c|c|c|}
\hline No & Analisis Bivariat & $p$ & $\overline{O R}$ \\
\hline 1. & \begin{tabular}{lr} 
Hubungan & \multicolumn{2}{r}{ Pencemaran } \\
Sumber Air & dengan \\
Kejadian Diare pada Anak \\
Balita
\end{tabular} & 0.033 & 3,45 \\
\hline 2. & $\begin{array}{l}\text { Hubungan perilaku ibu } \\
\text { dalam mencuci tangan } \\
\text { dengan kejadian diare pada } \\
\text { anak balita }\end{array}$ & 0,000 & 51,25 \\
\hline 3. & $\begin{array}{l}\text { Hubungan perilaku ibu } \\
\text { dalam merebus air minum } \\
\text { dengan kejadian diare pada } \\
\text { anak balita }\end{array}$ & 0,001 & 8,75 \\
\hline 4. & $\begin{array}{l}\text { Hubungan perilaku ibu } \\
\text { dalam menyimpan air } \\
\text { minum dengan kejadian } \\
\text { diare pada balita }\end{array}$ & 0,000 & 19,25 \\
\hline 5. & $\begin{array}{l}\text { Hubungan perilaku ibu } \\
\text { dalam membuang tinja } \\
\text { balita dengan kejadian diare } \\
\text { pada balita }\end{array}$ & 0,000 & 88,00 \\
\hline
\end{tabular}


1. Hubungan Pencemaran Sumber Air dengan Kejadian Diare pada Balita di Desa Sirkandi Kecamatan Purwareja Klampok Tahun 2016

Hasil analisis hubungan antara perilaku ibu dalam merebus air dengan kejadian diare pada balita diperoleh bahwa ada sebanyak 25 dari 28 $(89,3 \%)$ balita yang ibunya berperilaku tidak higienis (merebus air tidak sampai mendidih) menderita diare, sedangkan pada balita yang ibunya merebus air sampai mendidih ada 20 dari $41(48,8 \%)$ balita menderita diare. Hasil uji statistik diperoleh nilai $p=0,001(p<0,05)$ maka dapat disimpulkan ada perbedaan proporsi kejadian diare antara balita yang ibunya merebus air sampai mendidih dengan merebus air tidak sampai mendidih (ada hubungan yang signifikan perilaku merebus air dengan kejadian diare).

Tingginya tingkat risiko pencemaran sumber air bersih mempengaruhi kulitas air minum, sehingga menjadi tidak memenuhi syarat kesehatan. Hasil penelitian ini sejalan dengan penelitian Rina Mutiara Ginting (2009), yang menyatakan adanya hubungan antara tingkat risiko pencemaran sumber air dengan kualitas air dengan nilai $p=0.000$.

Sarana air bersih merupakan bangunan beserta peralatan dan perlengkapannya yang menyediakan dan mendistribusikan air kepada masyarakat. Sarana air bersih harus memenuhi persyaratan kesehatan agar tidak mengalami pencemaran, sehingga dapat diperoleh air yang baik sesuai dengan standar kesehatan.

Menurut Depkes. R.I. (1995) setiap sarana air bersih memiliki persyaratan yang berbedabeda, tetapi dari setiap persyaratan yang ada, syarat utama yang harus diperhatikan adalah jarak antara sarana air bersih dengan tempat pembuangan tinja. Persyaratan untuk tanah di Desa Sirkandi, Kecamatan Purwareja Klampok, Kabupaten Banjarnegara, jarak sarana air bersih dengan tempat pembuangan tinja tidak boleh kurang dari $10 \mathrm{~m}$. Hal ini agar sarana air bersih yang digunakan tidak terkontaminasi oleh kotoran tinja yang mengandung bibit penyakit penyebab diare (coliform).

Menurut penelitian Novel H. Tendean $(2012$,$) terdapat hubungan bermakna antara jarak$ sumber sarana air bersih dengan sumber pencemar dengan kandungan coliform di Desa Kapitu, Kecamatan Amurang Barat, Kabupaten Minahasa dengan $p$ value $=0,000(p<0,05)$. Coliform merupakan indikator pencemaran air oleh tinja. Coliform merupakan salah satu bakteri penyebab diare. Semakin tinggi kandungan coliform semakin tinggi kemungkinan untuk menyebabkan diare.

Sumber air bersih yang digunakan di Desa Sirkandi, Kecamatan Purwareja Klampok, Kabupaten Banjarnegara, sebagian besar (44,7\%) berupa sumur gali yang mepunyai jarak dengan tempat pembuangan tinja rata-rata kurang dari 10 m. Persyaratan konstruksi lain yang tidak dipenuhi adalah dinding sumur yang tidak diplester sedalam $3 \mathrm{~m}$, lantai sumur yang tidak kedap air dalam radius $1 \mathrm{~m}$, adanya keretakan pada lantai sumur dan saluran pembuangan limbah yang tidak berfungsi sehingga memungkinkan masuknya atau merembesnya air limbah ke dalam sumur.

Jarak dengan sumber pencemar merupakan salah satu variabel/item yang dinilai dalam penilaian tingkat risiko pencemaran sarana air bersih atau inspeksi sanitasi sarana air bersih. Semakin banyak penyimpangan pada item penilaian inspeksi sanitasi sarana air bersih berarti bahwa semakin tinggi tingkat risiko pencemaran sarana air bersih tersebut. Tingkat risiko pencemaran sarana air bersih menunjukkan tingkatan atau besarnya kemungkinan sebagai faktor risiko dalam menularkan penyakit. Tidak terpenuhinya atau penyimpangan pada item inspeksi sanitasi sarana air bersih tersebut diatas menyebabkan sarana air bersih tersebut berisiko untuk menularkan penyakit kepada penggunanya.

Upaya yang dapat dilakukan untuk memperkecil kemungkinan terjadinya pencemaran sumber air yaitu dengan memperhatikan syarat- syarat fisik dari sumber air seperti: jarak sumber air dengan sumber pencemar minimal 10 meter, lantai sumur sekurang-kurangnya berdiameter 1 meter dari dinding sumur dan kedap air, saluran pembuangan air limbah harus kedap air, tinggi bibir sumur minimal 0,8 meter, memiliki cincin (dinding) sumur minimal 3 meter dan memiliki tutup yang rapat.

Tidak terpenuhinya persyaratan konstruksi sumber air bersih yang memenuhi syarat, salah satunya disebabkan oleh kurangnya pengetahuan masyarakat tentang persyaratan sarana air bersih yang memenuhi syarat, sehingga perlu dilakukan sosialisasi tentang persyaratan sarana air bersih yang memenuhi syarat kesehatan melalui penyuluhan kepada masyarakat, kader desa siaga dan badan pengelola sarana air bersih yang ada di Desa Sirkandi, Kecamatan Purwareja Klampok, Kabupaten Banjarnegra.

Kegiatan lain yang dapat dilakukan untuk mengatasi masalah tingkat risiko pencemaran 
sumber air bersih di Desa Sirkandi, Kecamatan Purwareja Klampok, Kabupaten Banjarnegara adalah dengan melakukan kegiatan inspeksi sanitasi sarana air bersih. Menurut Depkes. R.I. (1995), salah satu upaya untuk mengetahui kualitas sarana air bersih diantaranya adalah dengan melakukan kegiatan pengawasan atau inspeksi sanitasi terhadap kualitas sarana air bersih. Tujuan isnpeksi sanitasi sarana air bersih adalah mengidentifikasi sumber sumber yang berpotensi menyebabkan terjadinya pencemaran. Melalui kegiatan ini dapat diperoleh informasi tentang risiko pencemaran dari setiap sarana air bersih yang ada sehingga dapat diambil langkah tindak lanjut untuk mengatasi pencemaran tersebut.

2. Hubungan Perilaku Ibu dalam Menyimpan Air Minum dengan Kejadian Diare pada Anak Balita di Desa Sirkandi, Kecamatan Purwareja Klampok, Kabupaten Banjarnegara Tahun 2016

Hasil analisis hubungan antara perilaku ibu dalam menyimpan air dengan kejadian diare pada balita diperoleh bahwa ada sebanyak 33 dari 36 $(91,7 \%)$ balita yang ibunya berperilaku tidak higienis (tidak menutup air minum dalam wadah yang tertutup) menderita diare, sedangkan pada balita yang ibunya menyimpan air minum dalam wadah yang tidak tertutup ada 12 dari $33(36,4 \%)$ balita menderita diare. Hasil uji statistik diperoleh nilai $p=0,000(p<0,05)$ maka dapat disimpulkan ada perbedaan proporsi kejadian diare antara balita yang ibunya menyimpan air minum dalam wadah yang tidak tertutup dengan menyimpan air minum dalam wadah tertutup (ada hubungan yang signifikan perilaku menyimpan air dengan kejadian diare).

Kebiasaan yang berhubungan dengan kebersihan perorangan yang penting dalam penularan penyakit diare adalah mencuci tangan. Mencuci tangan dengan sabun, terutama sesudah buang air besar, sesudah membuang tinja anak, sebelum menyuapi anak dan sebelum makan mempunyai dampak dalam kejadian diare (Depkes, 2005). Berdasarkan hasil penelitian diketahui bahwa 45 responden $(65,2 \%)$ tidak mencuci tangan dengan sabun sesudah buang air besar, sedangkan 24 responden $(34,8 \%)$ mencuci tangannya dengan sabun sesudah buang air besar.

Berdasarkan hasil analisis chi square menunjukkan bahwa $91,1 \%$ responden yang tidak mencuci tangannya dengan sabun sesudah buang air besar memiliki balita yang menderita diare 41, sedangkan $16,7 \%$ responden yang mencuci tangannya dengan sabun sesudah buang air besar memiliki balita yang menderita diare sebanyak 4 balita. Berdasarkan analisis bivariat menunjukkan bahwa ada hubungan yang signifikan antara perilaku mencuci tangan pakai sabun sesudah buang air besar dengan kejadian diare pada balita dengan nilai $p$ sebesar 0,000 ( $p$ $<0,05)$. Hasil analisis bivariat juga menunjukkan nilai odds ratio $(O R)=51,25$. Hal ini berarti bahwa pada balita yang mempunyai ibu tidak mencuci tangan dengan sabun sesudah buang air besar berpeluang menderita diare 51,25 kali lebih besar dari balita yang mempunyai ibu mencuci tangan dengan sabun sesudah buang air besar.

Hasil penelitian ini sejalan dengan penelitian Arie Kusumaningrum (2011) di Kelurahan Gendus, Palembang yang menunjukkan bahwa ada hubungan yang signifikan antara perilaku mencuci tangan pakai sabun sesudah buang air besar dengan kejadian diare pada balita dimana nilai $p$ yang didapat sebesar 0,00 .

Tangan merupakan bagian tubuh yang paling sering berhubungan dengan kuman yang menyebabkan penyakit dan menyebarkannya. Tangan juga merupakan bagian dari tubuh manusia yang paling sering berhubungan dengan mulut secara langsung, sehingga tangan menjadi salah satu perantara utama masuknya kuman atau mikroorganisme penyebab penyakit ke dalam tubuh manusia. Mulut menjadi pintu masuk kuman ke dalam saluran pencernaan, sehingga perilaku mencuci tangan sangat penting dan bermanfaat dalam mencegah penyebaran penyakit diare.

Tangan yang mengandung kuman penyakit jika tidak dibersihkan dengan benar dapat menjadi media masuknya kuman penyakit ke dalam tubuh manusia baik melalui kontak langsung dengan mulut maupun kontak dengan makanan atau minuman. Menurut Taufik (2008) bahwa perilaku mencuci tangan sangat penting untuk mencegah penyakit infeksi saluran pencernaan seperti diare. Cara mencuci tangan yang belum benar memungkinkan bakteri penyebab penyakit diare masih tetap berada pada tangan mereka. Perilaku mencuci tangan yang benar adalah menggunakan sabun dan air yang mengalir serta dilakukan pada lima waktu kritis utuk cuci tangan. Sabun berfungsi untuk melarutkan kotoran yang ada di tangan juga sebagai anti septik, sehingga kotoran yang menempel pada tangan hilang atau larut bersama air yang mengalir.

Kebiasaan mencuci tangan sudah dilakukan oleh ibu balita, tetapi belum dilakukan pada waktu yang tepat dan cara yang benar. Ibu balita di Desa 
Sirkandi, Kecamatan Purwareja Klampok, Kabupaten Banjarnegara sebagian besar sudah melakukan cuci tangan, tetapi belum dilakukan pada waktu yang benar dan cara yang benar, seperti: mencuci tangan saja tetapi tidak menggunakan sabun, tidak menggunakan air yang mengalir tetapi menggunakan air dalam ember atau kobokan. Demikian juga dalam hal waktu yang tepat untuk cuci tangan belum dilakukan sepenuhnya. Mereka baru melakukan cuci tangan pada waktu hendak makan dan sesudah makan. Waktu kritis untuk mencuci tangan yaitu sesudah buang air besar, sebelum menyuapi anak dan menyiapkan makanan belum dilakukan. Penyuluhan dan sosialisasi tentang waktu dan cara cuci tangan yang tepat kepada ibu balita perlu ditingkatkan lagi. Kegiatan ini dapat dilakukan melalui kegiatan kelas ibu balita, posyandu, konseling dan kunjungan rumah. Melalui kegiatan ini diharapkan ibu balita merubah perilakunya dari hanya sekedar mencuci tangan menjadi mencuci tangan pada waktu yang tepat dan cara yang benar.

3. Hubungan Perilaku Ibu dalam Merebus Air dengan Kejadian Diare pada Anak Balita di Desa Sirkandi, Kecamatan Purwareja Klampok, Kabupaten Banjarnegara Tahun 2016

Hasil analisis hubungan antara perilaku ibu dalam merebus air dengan kejadian diare pada balita diperoleh bahwa ada sebanyak 25 dari 28 $(89,3 \%)$ balita yang ibunya berperilaku tidak higienis (merebus air tidak sampai mendidih) menderita diare, sedangkan pada balita yang ibunya merebus air sampai mendidih ada 20 dari $41(48,8 \%)$ balita menderita diare. Hasil uji statistik diperoleh nilai $p=0,001(p<0,05)$ maka dapat disimpulkan ada perbedaan proporsi kejadian diare antara balita yang ibunya merebus air sampai mendidih dengan merebus air tidak sampai mendidih (ada hubungan yang signifikan perilaku merebus air dengan kejadian diare).

Perilaku responden berkaitan dengan pengolahan air sebelum dikonsumsi didapatkan hasil sebanyak $44(63,8 \%)$ telah melaksanakan pengolahan air dengan benar yaitu dengan cara merebus air sampai mendidih dan dibiarkan selama lebih dari lima menit, sedangkan 25 $(36,2 \%)$ responden belum melakukan pengolahan air dengan benar karena sebelum dikonsumsi air direbus tidak sampai mendidih dan dibiarkan selama lebih dari lima menit. Perilaku merebus air sampai mendidih selama lebih dari lima menit sangat baik dilakukan, karena dapat membunuh kuman patogen yang terdapat dalam air yang dikonsumsi. Hal ini sesuai pendapat Aimyaya (2009) bahwa cara yang efektif dalam memasak air adalah merebus air yang akan dikonsumsi hingga mendidih. Cara ini sangat efektif untuk mematikan semua patogen yang ada dalam air seperti virus, bakteri, spora, fungi dan protozoa. Lama waktu air mendidih yang dibutuhkan adalah berkisar lima menit, sepuluh menit dan dua puluh menit. Direkomendasikan selama lima menit, karena dalam waktu tersebut sudah cukup untuk membunuh semua kuman patogen yang ada dalam air.

Memasak air merupakan cara yang paling baik untuk proses disinfeksi air di rumah. Supaya proses disinfeksi menjadi lebih efektif maka air dibiarkan mendidih selama lima sampai sepuluh menit. Hal tersebut bertujuan agar semua kuman, spora, kista dan telur cacing sehingga air bersifat bebas kuman. Selain itu proses pendidihan juga dapat mengurangi kesadahan karena dalam proses pendidihan terjadi penguapan $\mathrm{CO} 2$ dan pengendapan $\mathrm{CaCO} 3$ (Budiman Chandra, 2007).

Berdasarkan hasil penelitian diketahui bahwa 28 responden $(40,6 \%)$ tidak merebus air sampai mendidih sebelum dikonsumsi, sedangkan 41 responden $(59,4 \%)$ sudah merebus air sebelum dikonsumsi sampai mendidih. Perilaku responden dalam mengelola air sebelum dikonsumsi sudah benar yaitu dengan merebusnya terlebih dahulu, akan tetapi mereka tidak semuanya merebus sampai mendidih dan membiarkannya mendidih selama minimal lima menit. Hal ini dikarenakan anggapan mereka bahwa dengan merebus air saja semua kuman dalam air sudah mati. Upaya yang dapat dilakukan untuk mengatasi hal ini yaitu dengan melakukan penyuluhan tentang pencegahan diare melalui cara merebus air sampai mendidh selama minimal lima menit kepada ibu balita. Kegiatan ini dapat dilakukan pada kegiatan posyandu, kelas ibu balita, konseling, dan kunjungan rumah.

Dari hasil analisis chi square menunjukkan bahwa 89,3\% responden yang tidak merebus air sebelum dikonsumsi sampai mendidih memiliki balita yang menderita diare sebayak 25, sedangkan 48,6\% responden yang merebus air sampai mendidih sebelum dikonsumsi memiliki balita yang menderita diare sebanyak 20 balita. Berdasarkan analisis bivariat menunjukkan bahwa ada hubungan yang signifikan antara perilaku mencuci tangan pakai sabun sesudah buang air besar dengan kejadian diare pada balita dengan nilai $p$ sebesar $0,001(p$ $<0,05)$. Hasil analisis juga menunjukkan nilai odds ratio $(O R=8,75)$. Hal ini berarti bahwa pada balita yang ibunya tidak merebus air sampai mendidih minimal selama lima menit mempunyai 
peluang menderita diare 8,75 kali lebih besar dari balita yang ibunya merebus air sampai mendidih selama minimal lima menit.

Merebus air akan mengurangi kontaminasi kuman pada air terutama bila terkontaminasi dengan alat dapur. Hasil penelitian ini sejalan dengan penelitian yang dilakukan oleh Siti Amaliah (2010) di Kecamatan Bendosari, Kabupaten Sukoharjo yang menjelaskan adanya hubungan yang signifikan antara perilaku merebus air dengan kejadian diare pada balita dengan nilai $p=0,00$.

4. Hubungan Perilaku Ibu dalam Menyimpan Air Minum dengan Kejadian Diare pada Anak Balita di Desa Sirkandi, Kecamatan Purwareja Klampok, Kabupaten Banjarnegara Tahun 2016

Hasil analisis hubungan antara perilaku ibu dalam menyimpan air dengan kejadian diare pada balita diperoleh bahwa ada sebanyak 33 dari 36 $(91,7 \%)$ balita yang ibunya berperilaku tidak higienis (tidak menutup air minum dalam wadah yang tertutup) menderita diare, sedangkan pada balita yang ibunya menyimpan air minum dalam wadah yang tidak tertutup ada 12 dari $33(36,4 \%)$ balita menderita diare. Hasil uji statistik diperoleh nilai $p=0,000(p<0,05)$ maka dapat disimpulkan ada perbedaan proporsi kejadian diare antara balita yang ibunya menyimpan air minum dalam wadah yang tidak tertutup dengan menyimpan air minum dalam wadah tertutup (ada hubungan yang signifikan perilaku menyimpan air dengan kejadian diare).

Berdasarkan hasil analisis hubungan antara perilaku ibu dalam menyimpan air minum dengan kejadian diare pada balita didapatkan hasil bahwa ada sebanyak $36(52,2 \%)$ ibu balita yang tidak menyimpan air minum secara higienis mempunyai balita yang menderita diare sebanyak 33 (91,7\%), sedangkan pada ibu balita yang menyimpan air minumnya secara higienis didapatkan balita yang menderita diare sebanyak $12(36,4 \%)$. Hasil uji statistik diperoleh nilai $p=$ 0,000, maka dapat disimpulkan ada perbedaan proporsi kejadian diare pada balita yang ibunya menyimpan air minum dalam wadah tertutup dengan balita yang ibunya menyimpan air minum dalam wadah yang tidak tertutup (ada hubungan yang signifikan antara perilaku menyimpan air minum dengan kejadian diare). Berdasarkan hasil analisis diperoleh nilai $O R=19,25$, artinya balita yang mempunyai ibu berperilaku menyimpan air minum dalam wadah yang tidak tertutup mempunyai peluang 19,25 kali menderita diare dibandingkan balita yang mempunyai ibu berperilaku menyimpan air minum dalam wadah tertutup.

Makanan atau minuman yang ditempatkan pada tempat yang tidak tertutup akan menyebabkan air/makanan tersebut dapat dihinggapi lalat atau debu yang memungkinkan masuknya bibit penyakit penyebab diare sehingga akan menyebabkan orang yang mengkonsumsinya menderita diare.

Makanan atau minuman yang kotor akan berbahaya bagi anggota keluarga karena dapat menyebabkan kejadian diare, sehingga agar keamanan makanan terjaga diusahkan agar menyimpan makanan atau air minum pada tempat yang dingin dan tertutup seperti lemari makan atau meja yang ditutup dengan tudung saji (Toyo, 2005).

Berdasarkan penelitian yang dilakukan dapat diketahui bahwa belum seluruh responden menyimpan air minum yang telah dimasak dalam wadah-wadah tertutup. Upaya yang dapat dilakukan untuk mengatasi hal ini adalah dengan melakukan penyuluhan mengenai pentingnya menyimpan air minum dalam wadah yang tertutup untuk mencegah diare. Penyuluhan dapat dilakukan melalui posyandu, kelas ibu balita, konseling pada klinik sanitasi dan kunjungan rumah.

5. Hubungan Perilaku Ibu dalam Membuang Tinja Balita dengan Kejadian Diare pada Anak Balita di Desa Sirkandi, Kecamatan Purwareja Klampok,Kabupaten Banjarnegara Tahun 2016

Hasil analisis hubungan antara perilaku ibu dalam membuang tinja balita dengan kejadian diare pada balita diperoleh bahwa ada sebanyak 40 dari $42(95,2 \%)$ balita yang ibunya membuang tinja bayi/balita pada tempat yang tidak memenuhi syarat (tidak dibuang ke septic tank) menderita diare, sedangkan pada balita yang ibunya membuang tinja bayi/balita pada tempat yang memenuhi syarat ada 5 dari $27(18,5 \%)$ balita menderita diare. Hasil uji statistik diperoleh nilai $p$ $=0,000(p<0,05)$ maka dapat disimpulkan ada perbedaan proporsi kejadian diare antara balita yang ibunya membuang tinja bayi/balita pada tempat yang memenuhi syarat dengan membuang tinja bayi balita pada tempat yang tidak memnuhi syarat (ada hubungan yang signifikan perilaku membuang tinja bayi/balita dengan kejadian diare).

Berdasarkan analisis bivariat hubungan antara perilaku membuang tinja balita kejadian diare didapat nilai $p$ sebesar 0,000 atau $p<0,05$, maka secara statistik dikatakan ada hubungan yang signifikan antara perilaku membuang tinja 
balita kejadian diare. Hasil perhitungan odds ratio $(O R)$ diperoleh nilai 88,0. Hal ini menunjukan bahwa risiko untuk terjadinya diare pada balita yang ibunya membuang tinja balitanya pada tempat yang tidak memenuhi syarat yaitu 88 kali lebih besar bila dibandingkan balita yang ibunya membuang tinja balitanya pada tempat yang memnuhi syarat.

Penggunaan jamban mempunyai dampak besar dalam penularan penyakit diare. Hasil penelitian ini sejalan dengan penelitian yang dilakukan oleh Wulandari (2009) di Desa Blimbing, Kecamatan Sambirejo, Kabupaten Sragen, yang menyatakan bahwa ada hubungan antara perilaku membuang tinja dengan kejadian diare pada balita dengan nilai $p=0,00$

$(p<0,05)$.

Tempat pembuangan tinja yang tidak memenuhi syarat sanitasi akan meningkatkan risiko terjadinya diare pada anak balita sebesar dua kali lipat dibandingkan dengan keluarga yang mempunyai perilaku membuang tinja yang memenuhi syarat sanitasi (Wulandari, 2009)

Berdasarkan wawancara yang dilakukan kepada responden, sebagian responden membuang tinja bayi/balita pada tempat yang tidak memenuhi syarat. Mereka membuang tinja bayi/balita ke kebun, tempat sampah, selokan atau saluran pembuangan air limbah. Hal ini dikarenakan balita belum terbiasa buang air besar di jamban. Mereka buang air besar di kamar mandi, di halaman, di kebun atau di celana. Tinja tersebut kemudian dibuang dengan cara membersihkan dengan air, dan air tersebut dilewatkan ke saluran air atau dibuang ke kebun begitu saja. Sebagian dari mereka juga menggunakan pampers, sehingga tinja dibuang bersamaan dengan pampers yang dipakai. Pampers tersebut di buang ke kebun atau tempat sampah. Mereka juga beranggapan bahwa tinja bayi/balita tidak berbahaya. Untuk itu perlu dilakukan upaya agar tinja balita dapat dibuang pada tempat yang memenuhi syarat. Upaya yang dapat dilakukan yaitu dengan melatih balita sedini mungkin buang air besar di jamban, mencuci terlebih dahulu pampers, popok atau celana yang mengandung tinja dan membuangnya pada tempat penampungan tinja.

Menurut Depkes. R.I. (2000), tinja bayi/balita juga berbahaya karena mengandung bibit penyakit dalam jumlah besar, sehingga tinja bayi dapat menularkan penyakit pada balita itu sendiri atau juga pada orang tuanya. Tinja yang dibuang di tempat terbuka dapat digunakan oleh lalat untuk bertelur dan berkembang biak. Lalat berperan dalam penularan penyakit melalui tinja (faecal borne desease). Lalat senag menempatkan telurnya pada kotoran manusia yang terbuka kemudian lalat tersebut hinggap pada kotoran manusia, kemudian hinggap pada makanan yang dikonsumsi manusia. Hasil penelitian ini sejalan dengan penelitian yang dilakukan oleh Wibowo (2004) yang menyimpulkan ada hubungan bermakna antara kejadian diare dengan tempat pembuangan tinja. Penelitian lain (Zubir, 2006) menyimpulkan bahwa selain sumber air minum, tempat pembuangan tinja yang tidak memenuhi syarat sanitasi dapat mencemari lingkungan pemukiman, tanah dan sumber air. Dari lingkungan yang tercemar tinja terakumulasi dengan perilaku yang tidak higienis, melalui makanan atau air minum yang tercemar tinja maka dapat menimbulkan diare.

\section{Kesimpulan:}

1. Tingkat risiko pencemaran sumber air bersih di Desa Sirkandi, Kecamatan Purwareja Klampok, Kabupaten Banjarnegara tahun 2016 adalah: 27 sarana $(39,1 \%)$ mempunyai tingkat risiko pencemaran rendah dan sedang, 42 sarana $(60,9 \%)$ mempunyai tingkat risiko pencemaran tinggi.

2. Ada hubungan yang signifikan antara pencemaran sumber air dengan kejadian diare pada anak balita di Desa Sirkandi, Kecamatan Purwareja Klampok, Kabupaten Banjarnegara dengan nilai $p=0,033$, $O R=3,45$

3. Ada hubungan yang signifikan antara perilaku ibu dalam mencuci tangan dengan kejadian diare pada anak balita di Desa Sirkandi, Kecamatan Purwareja Klampok, Kabupaten Banjarnegara dengan nilai $p=0,000, O R=51,25$

4. Ada hubungan yang signifikan antara perilaku ibu dalam merebus air dengan kejadian diare pada anak balita di Desa Sirkandi, Kecamatan Purwareja Klampok, Kabupaten Banjarnegara dengan nilai $p=0,001, O R=8,75$

5. Ada hubungan yang signifikan antara perilaku ibu dalam menyimpan air minum dengan kejadian diare pada anak balita di Desa Sirkandi, Kecamatan Purwareja Klampok, Kabupaten Banjarnegara dengan nilai $p=0,000, O R=19,25$

6. Ada hubungan yang signifikan antara perilaku ibu dalam membuang tinja balita dengan kejadian diare pada anak balita di Desa Sirkandi, Kecamatan Purwareja Klampok, Kabupaten Banjarnegara dengan nilai $p=0,000, O R=88,0$

\section{Daftar Pustaka:}


Arie Kusumaningrum, 2011, Pengaruh Perilaku Hidup Bersih dan Sehat Tatanan Rumah Tangga terhadap Kejadian Diare di Kelurahan Gendus, Palembang,http://eprints.unsri.ac.id/889/1/ makalah_phbs_keluarga

Aris Santjaka, 2011, Statistik untuk Penelitian Kesehatan 1, Yogyakarta: Nuha Medika

Aziz Alimul Hidayat, 2008, Metode Penelitian Kebidanan dan Teknik Analisis Data, Jakarta : Salemba Medika

Budiman Candra, 2007, Pengantar Kesehatan Lingkungan, Jakarta: EGC

Departemen Kesehatan RI, 1990, Syarat syarat dan Pengawasan Kualitas Air,Permenkes No.416/Menkes/Per/IX/1990, Jakarta : Depkes RI

2001, Panduan Konseling Bagi Petugas Klinik Sanitasi di Puskesmas, Jakarta : Depkes RI

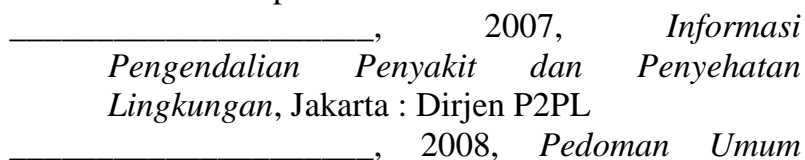
Pengelolaan Kegiatan Peningkatan Perilaku Cuci Tangan Pakai Sabun, Jakarta : Dirjen P2PL 2011, Panduan Sistem Surveilen Air Minum dan Sanitasi, Jakarta : Dirjen P2PL

2011, Buku Pedoman Pengendalian Penyakit Diare, Jakarta : Dirjen P2PL , 2014, Perilaku Mencuci Tangan Pakai Sabun di Indonesia, Jakarta : Pusat Data dan Informasi Kesehatan RI

Dinas Kesehata Propinsi Jawa Tengah, 2001, Panduan Konseling Bagi Petugas Kliinik Sanitasi di Puskesmas, Semarang: Dinas Keshatan Propinsi Jawa Tengah

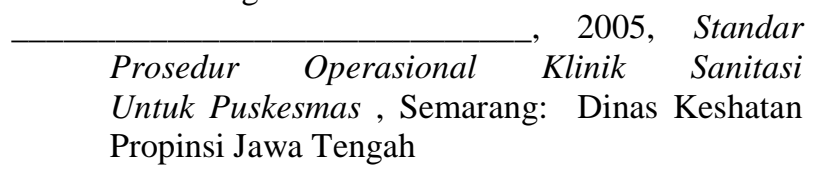
Propinsi Jawa Tengah

Tetap Penanggulangan KLB Bencana Propinsi Jawa Tengah, Semarang, Dinas Kesehatan propinsi Jawa Tengah

Indan Entjang, 2008, Ilmu Kesehatan Masyarakat, Bandung : Citra Aditya Bakti

Puskesmas Purwareja Klampok 2, 2015, Profil Kesehatan, Banjarnegara, Puskesmas Purwareja Klampok 2 2015, Profil dan Data Dasar Program PL, Banjarnegara, Puskesmas Purwareja Klampok 2
Soekidjo Notoatmodjo, 1997, Ilmu Kesehatan Masyarakat, Jakarta : Rhineka Cipta , 2002, Metodologi Penelitian, Jakarta : Rhineka Cipta

Siti Amaliah, 2010, Hubungan Sanitasi Lingkungan dan Faktor Budaya dengan Kejadian Diare pada Anak Balita di Desa Toriyo Kecamatan Bendosari Kabupaten Sukoharjo

Suharsimi Arikunto, 2006, Prosedur Penelitian Suatu Pendekatan Praktek, Jakarta : Rineka Cipta

Suyono, 2012, Ilmu Kesehatan Masyarakat Dalam Konteks Kesehatan Lingkungan, Jakarta : EGC

Totok Sutrisno, 1987, Teknologi Penyediaan Air Bersih, Jakarta : Rineka Cipta

Widoyono, 2011, Penyakit Tropis, epidemiologi, pencegahan dan pemberantasan, Jakarta : Erlangga

Wulandari P, 2009, Hubungan Antara Faktor Lingkungan dan Faktor Sosiodemografi dengan Kejadian Diare pada Balitadi Desa Blimbing Kecamatan Sambirejo Kabupaten Sragen, http: //female.store.co.id/image/media kesehatan

Zulkarnaen8.blogspot.co.id, Diare pada Anak Balita, 2016 